\title{
The Dyeing Properties of Woody Fiber Regenerated from Waste MDF by Reactive Dyes ${ }^{1}$ 蝇
}

\author{
Seon-Gyeong $\mathrm{Ju}^{2} \cdot$ JeongKwan Roh (iD) $2, \dagger$
}

\begin{abstract}
This study aims to review the relations between the dyeing conditions (i.e., dye concentration, addition amounts of salt and alkali, and dyeing temperature) and dyeing properties and color fastness to light for identifying the optimal dyeing conditions when dyed regenerated woody fibers were obtained through the defibration of waste medium density fiberboard (MDF) using reactive Red H-E3B (Bis-monochlorotriazine (MCT)/MCT type) and reactive Red RB133\% (Bis-MCT/Vinyl sulphone type). The dyeing yield (K/S) obtained using two types of reactive dyes increased as the dye concentration increased by 1-10\% (on the weight of fiber (OWF)). In addition, the K/S of H-E3B was higher than that of RB133\% irrespective of the dye concentration. The color difference of H-E3B after ultraviolet (UV) radiation was lower than that of RB133\%, denoting good resistance to discoloration by UV. As the amount of sodium sulfate increased, the color difference and $\mathrm{K} / \mathrm{S}$ also increased, and the adequate salt content was determined to be $50-70 \mathrm{~g} / \mathrm{L}$. Further, the color difference and K/S significantly increased only the addition of $2 \mathrm{~g} / \mathrm{L}$ of sodium carbonate; however, almost no difference was observed when more than $2 \mathrm{~g} / \mathrm{L}$ of sodium carbonate was added. The addition amount of sodium carbonate was adequate $5-10 \mathrm{~g} / \mathrm{L}$ to dyeing the fiber and the $\mathrm{pH}$ at this addition level was 10 . The dyeing yield of H-E3B increased when the dyeing temperature increased; however, it subsequently decreased after the dyeing temperature became $80^{\circ} \mathrm{C}$. The dyeing yield of RB133\% was almost the same up to $60-70^{\circ} \mathrm{C}$ but declined subsequently. Thus, the adequate temperatures were $80^{\circ} \mathrm{C}$ and $60^{\circ} \mathrm{C}$ for $\mathrm{H}$-E3B and $\mathrm{RB} 133 \%$, respectively. If the waste MDF woody fiber was dyed under the aforementioned optimal conditions, dyed regenerated woody fiber can be obtained having the following colors: 1.5 to $2.0 \mathrm{R}$ with the H-E3B dye and 9.6 to 10.0 PR with RB133\%.
\end{abstract}

Keywords: waste MDF, dyed regenerated woody fiber, reactive dyes, color difference, K/S, light fastness

\section{INTRODUCTION}

Medium density fiberboard (MDF) is the most commonly used wooden panel material and has exhibited an average demand of 2,150,000 $\mathrm{m}^{3} / \mathrm{year}$ from 2006 to 2016 in Republic of Korea (FAO). Furthermore, approximately 2 million $\mathrm{m}^{3}$ of waste MDF is estimated to be produced every year when the average lifespan of the MDF products (used for furniture and building materials) is presumed to be a decade. However, despite increasing interests and investments in waste recycling, MDF is barely recycled as a non-thermal recycled mat-

\footnotetext{
1 Date Received January 29, 2019, Date Accepted February 18, 2019

2 Department of Interior Materials Engineering, Gyeongnam National University of Science Technology, Jinju 52725, Republic of Korea

† Corresponding author: JeongKwan Roh (e-mail: arohjk@gntech.ac.kr, ORCID: 0000-0002-3146-951X)
} 
ter even though it is the most demanded wooden panel in Republic of Korea. A previous study reviewed the manufacturability of the dyed regenerated woody fiber (Re-WF) to use waste MDF (which can be easily observed in the surroundings) as a raw material for manufacturing interior goods (Ju and Roh, 2017). Upon comparing and reviewing the dyeing properties and color fastness to light of virgin fiber and regenerated fiber with six types of reactive dyes (bis-monochlorotriazine type and vinyl sulphone type; red, yellow, and blue), three types of vat dyes (anthraquinone type), three types of direct dyes (diazo type) commonly used in dyeing cellulose fibers, and the natural dyes obtained from cape jasmine and sappan wood, the manufacturability of the dyed fiber was confirmed; however, the color fastness to light was poor.

Several studies, including a study on the ACQ-preserved wood color (Lee and Choi, 2018), a study on the color change of heat-treated wood (Hidayat et al., 2017 and Yoon et al., 2009), a study on the color change in wood through natural dyeing methods (Moon et al., 2007), and a study on the usage of the dyeing components of Neolitsea sericea Koidz bark as a natural dye for hanji (Lee et al., 2006), have investigated wood and wooden materials; however, no studies have been conducted on dyeing the woody fiber with reactive dyes. Furthermore, there are several studies that have investigated the dyeing properties of cationic agent treated cotton fiber with reactive dye (Jung et al., 1994), effects based on the types and addition amount of Canadian horseweed on the dyeing properties and color fastness while dyeing cellulose fiber using the three-primary-color reactive dye (Kim et al., 2010), the dyeing properties of the novel regenerated cellulosic fiber (Koh et al., 2004; 2005), and the superiority of ultrasonic energy dyeing when compared to conventional dyeing in cellulosic fibers (Bhatri et al., 2012; Khatri et al., 2016) and bamboo fiber textile (Larik et al., 2015), using reactive dyes; however, no studies have been conducted on regenerated woody fiber. While dyeing with reactive dyes, a covalent bond is formed by the addition or substitution reaction between the reactive group of dye (mainly vinyl sulphone or chlorotriazine groups) and hydroxyl group of cellulose, resulting in color formation with different colors and color fastness values in accordance with the dyeing conditions. Herein, the optimal dyeing conditions, i.e, OWF, temperature, $\mathrm{pH}$, and amount of auxiliaries, were identified when dyeing regenerated wood fibers using red-based reactive dyes (bis-monochlorotriazine: bis- MCT/MCT and bis-monochlorotriazine/vinyl sulphone: bis-MCT/VS type).

\section{MATERIALS and METHODS}

\subsection{Materials}

\subsubsection{MDF}

MDF (12-mm thickness and 0.62 specific gravity), which was manufactured using domestic pitch pine (Pinus rigida M.) and urea resin, was obtained from an industrial source to acquire Re-WF.

\subsubsection{Dyes and reagents}

Red H-E3B of bis-MCT/MCT type and Red RB133\% of bis-MCT/VS type were used as reactive dyes. Table 1 presents the types and major characteristics of the used dyes. The extra pure reagents were used as sodium sulfate and sodium carbonate. The SNOPOL SR-140 (Snogen Co.) anionoid was used as the soaping agent, and the SUPERFIX RF (Snogen Co.) cationoid was used as the fixation agent.

\subsection{Methods}

\subsubsection{Preparation of the regenerated fiber}

To obtain the regenerated fiber, $250 \mathrm{ml}$ of distilled water was added to the MDF that had been cut into $50 \times 50 \times 12 \mathrm{~mm}$, which was further immersed at 
The Dyeing Properties of Woody Fiber Regenerated from Waste MDF by Reactive Dyes

Table 1. Kinds and molecular weight of used dyes

\begin{tabular}{|c|c|c|c|c|}
\hline Dye type & $\begin{array}{c}\text { Commercial } \\
\text { name }\end{array}$ & $\begin{array}{l}\text { C.I. Generic } \\
\text { name }\end{array}$ & $\begin{array}{c}\text { Molecular } \\
\text { formula }\end{array}$ & $\begin{array}{l}\text { Molecular } \\
\text { weight }\end{array}$ \\
\hline $\begin{array}{c}\text { Bis-MCT/MCT: } \\
\text { (Bis-Monochlorotriazine) }\end{array}$ & Red H-E3B & $\begin{array}{l}\text { Reactive } \\
\text { Red } 120\end{array}$ & & 1469.98 \\
\hline $\begin{array}{c}\text { Bis-MCT/VS } \\
\text { (Bis-Monochlorotriazine/Vinyl sulfone) }\end{array}$ & $\begin{array}{c}\text { Red RB } \\
133 \%\end{array}$ & $\begin{array}{l}\text { Reactive } \\
\text { Red } 198\end{array}$ & & 984.21 \\
\hline
\end{tabular}

$25^{\circ} \mathrm{C}$ for 48 hours and defibrated in a home-use mixer for $5 \mathrm{~min}$. Then, it was dried and manufactured after being screened through a $300-\mu \mathrm{m}$ screen.

\subsubsection{Dyeing}

Fig. 1 depicts the entire dyeing process. the regenerated fiber was inserted into a tall beaker, and each dyeing condition was reviewed with respect to the following basic conditions: $5 \%$ dye (OWF), liquid ratio 1:50, 50 $\mathrm{g} / \mathrm{L}$ of $\mathrm{Na}_{2} \mathrm{SO}_{4}$, and $20 \mathrm{~g} / \mathrm{L}$ of $\mathrm{Na}_{2} \mathrm{CO}_{3}$ for $80 \mathrm{~min}$. at $80^{\circ} \mathrm{C}$. Dyeing was performed under these conditions by varying the addition amounts of the dye $(0,1,3,5,7$, and $10 \%, \mathrm{OWF})$, the addition amounts of $\mathrm{Na}_{2} \mathrm{SO}_{4}(0$, 10, 30, 50, and $70 \mathrm{~g} / \mathrm{L}$ ), the addition amounts of $\mathrm{Na}_{2} \mathrm{CO}_{3}$ $(0,2,5,10$, and $30 \mathrm{~g} / \mathrm{L})$, and the dyeing temperature (60, 70, 80, and $\left.90^{\circ} \mathrm{C}\right)$. Then, soaping treatment was performed for $10 \mathrm{~min}$. in a liquid ratio of 1:50 with an addition $1 \mathrm{~g} / \mathrm{L}$ of the soaping agent at $90^{\circ} \mathrm{C}$.

After soaping treatment, fixation treatment was performed for $20 \mathrm{~min}$. in a liquid ratio of 1:50 with $2 \%$ OWF addition amount of the fixing agent at $60^{\circ} \mathrm{C}$ and then rinsed with water.
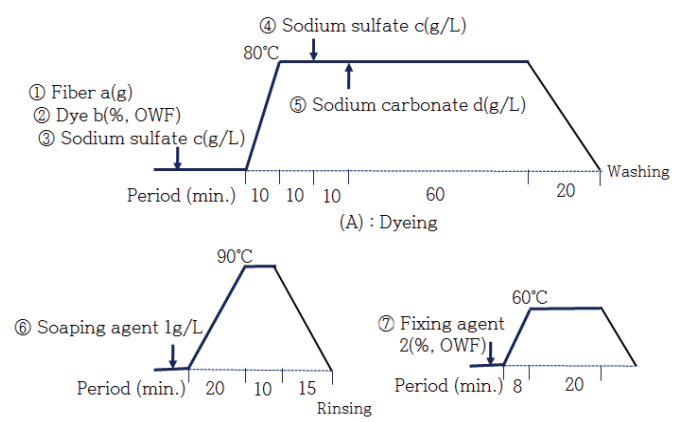

(B) : Soaping

(C) : Fixing

Fig. 1. Dyeing profiles of Re-WF.

Notes: Standard conditions : $a=2 \mathrm{~g}, \mathrm{~b}=5 \%, \mathrm{c}=25+25 \mathrm{~g} / \mathrm{L}$, $\mathrm{d}=20 \mathrm{~g} / \mathrm{L}$ liquor ratio $1: 50$

\subsubsection{Preparation of dyed fiber sheet}

The sheet required for measuring the dyeing affinity, coloring, and color fastness to light was manufactured by adding the same amount of dyeing liquid and distilled water to the regenerated fiber dyed in different conditions using two types of reactive dyes that are processed in a mini-mixer for 2 min., filtered through the Whatman filtering paper, and compressed for $5 \mathrm{~min}$. at $50^{\circ} \mathrm{C}$. 


\subsubsection{Color property measurement}

The surface color of the regenerated dyed fiber was measured using Minolta CM-3800d (Japan). The color difference was obtained by dyeing based on the non-dyed Re-WF sheet. Further, the color difference after UV irradiation was calculated based on the differences of $\mathrm{L}^{*}, \mathrm{a}^{*}$, and $\mathrm{b}^{*}$ before and after the irradiation. The K/S value was calculated using the following Kubelka-Munk equation after the surface reflectance of each dyed sample was measured.

$$
\mathrm{K} / \mathrm{S}=(1-\mathrm{R})^{2} / 2 \mathrm{R}
$$

K: Absorption coefficient

S: Scattering coefficient

R: Reflectance coefficient

\subsubsection{Assessment of the color fastness to light}

The color fastness to light of the sheet manufactured using the fiber dyed with each dyes was assessed using the color differences in the CIE Lab color space before and after UV irradiation was performed for certain times using the accelerated weathering tester (QUV/SP, USA), UVB-313 lamp, and illumination of $0.67 \mathrm{~W} / \mathrm{m}^{2}$ at a temperature of $50^{\circ} \mathrm{C}$.

\section{RESULTS and DISCUSSION}

The dyeing process of cellulose fiber with reactive dye comprises the following phases: Phase A, where the reactive dye is adsorbed onto the cellulose surface and is permeated into the fiber, Phase $\mathrm{B}$, where a covalent bond, such as an ether bond, is formed between the reactive group of the dye (mainly vinyl sulphone or chlorotriazine) and the hydroxyl group of cellulose, and Phase $\mathrm{C}$ or the stage of washing and fixation, which eliminates the alkali that has been added to induce the covalent bond for preventing hydrolysis or fiber damage and eliminates the non-reactive dye (CIBA-GEIGY, 1990). Furthermore, the dyeing properties vary according to the conditions that have been applied in each phase.
The dye concentration that directly affects the spread of the dye, the addition amount of sodium sulfate as an inert salt for relieving the electrostatic resistance between the anions of cellulose and dye (Donnan potential), the amount of sodium carbonate added to stimulate the additional reaction or nucleophilic substitution (SN2) as the alkaline catalyst. Therefore, the relations between these dyeing conditions and the dyeing affinity were examined.

\subsection{Effect of dyeing concentration on dyeing properties and color fastness}

For the dyeing properties of cellulose fiber with a reactive dye, substantivity is very important as the dye distribution between the fiber and reactive dye in Phase A. Because only a limited amount of dye is absorbed onto the surface of the cellulose fiber, adding the dye above the saturating concentration for the surface may reduce the substantivity.

Table 2 presents the colors and color differences according to the dye concentration observed while dyeing the Re-WF with the reactive dyes of H-E3B (Bis-MCT/MCT type) and RB133\% (Bis-MCT/VS type). First, the color of the Re-WF (Control) and equally treated Re-WF (Control-Tre) without the addition of the dye was yellow, with a tint of yellow-red (YR) at $0.2 \mathrm{Y}$ and $0.4 \mathrm{Y}$, respectively. On the contrary, the Re-WF (Control-Tre) that was equally dyed without the addition of the dye exhibited a decrease in value, a slight increase in chroma, and the color difference was 3.8. This may be because of heating or the addition of additives. According to the National Bureau Standard (NBS) in the United States, this difference is evaluated as "appreciable" (color difference of 3.6-6.0).

With H-E3B, the colors observed using a dye concentration of $1 \%-10 \%$ were $0.2 \mathrm{R}$ to $2.6 \mathrm{R}$. In a low concentration, the color was closer to red, whereas the color was close to RP when the concentration increased. However, the color difference of the dyed fiber with 
The Dyeing Properties of Woody Fiber Regenerated from Waste MDF by Reactive Dyes

Table 2. Color changes of the dyed Re-WF by addition level of reactive dyes

\begin{tabular}{ccccccccc}
\hline \multirow{2}{*}{ Type of dye } & $\begin{array}{c}\text { Addition level } \\
\text { of dye } \\
(\%, \text { OWF })\end{array}$ & \multicolumn{3}{c}{ CIE Lab color space } & \multicolumn{3}{c}{ Munsell color system } \\
\cline { 2 - 9 } & 0 & 71.4 & 5.8 & 24.5 & 3.8 & $0.4 \mathrm{Y}$ & 7.1 & 3.8 \\
\hline \hline \multirow{3}{*}{ Red H-E3B } & 1 & 50.6 & 42.1 & 7.8 & 45.9 & $0.2 \mathrm{R}$ & 4.9 & 10.3 \\
& 3 & 43.8 & 47.9 & 9.2 & 53.8 & $0.9 \mathrm{R}$ & 4.3 & 11.5 \\
& 5 & 41.5 & 49.4 & 10.8 & 56.0 & $1.5 \mathrm{R}$ & 4.1 & 11.9 \\
& 7 & 39.9 & 49.0 & 12.1 & 56.3 & $2.0 \mathrm{R}$ & 3.9 & 11.7 \\
& 10 & 38.1 & 47.8 & 13.3 & 56.3 & $2.6 \mathrm{R}$ & 3.8 & 11.3 \\
\hline \multirow{2}{*}{ Red RB 133\% } & 0 & 71.4 & 5.8 & 24.5 & 3.8 & $0.4 \mathrm{Y}$ & 7.1 & 3.8 \\
& 1 & 52.8 & 34.3 & 7.8 & 38.6 & $0.6 \mathrm{R}$ & 5.2 & 8.5 \\
& 3 & 44.9 & 41.1 & 5.4 & 49.1 & $9.6 \mathrm{RP}$ & 4.4 & 10.0 \\
& 5 & 41.3 & 43.1 & 5.8 & 52.5 & $9.9 \mathrm{RP}$ & 4.1 & 10.4 \\
& 7 & 40.3 & 44.1 & 5.9 & 53.9 & $10.0 \mathrm{RP}$ & 3.9 & 10.6 \\
& 10 & 37.5 & 44.6 & 7.1 & 55.7 & $0.7 \mathrm{R}$ & 3.7 & 10.5 \\
\hline
\end{tabular}

respect to the non-dyed Re-WF was 45.9-56.3, which rapidly increased at a low concentration but almost no difference could be observed at a concentration of more than $5 \%$. The colors of RB133\% of the Bis-MCT/VS type were $0.6 \mathrm{R}-0.7 \mathrm{R}$ and 9.6-10.0RP at dye concentrations of $1 \%$ and $10 \%$, respectively, which were reddish and were almost close to red. Further, almost no difference in color could be observed in accordance with the dye concentration. However, the color difference was 38.655.7, exhibiting an increasing trend as the dye concentration increased.

Fig. 2 shows the dyeing yields observed in accordance with the dyeing concentration of the reactive dye. The dyeing yields of H-E3B (maximum wavelength of 540 $\mathrm{nm}$ ) and RB133\% (maximum wavelength of $530 \mathrm{~nm}$ ) increased when the dye concentration increased from $1 \%$ to $10 \%$. The K/S of H-E3B (Bis-MCT/MCT type) was higher than that of RB133\% (Bis-MCT/VS type) at all the dye concentrations. Therefore, the adequate addition amount of dye should be adjusted for achieving the target color. The color will becomes closer to red if the concentration increases up to $10 \%$.

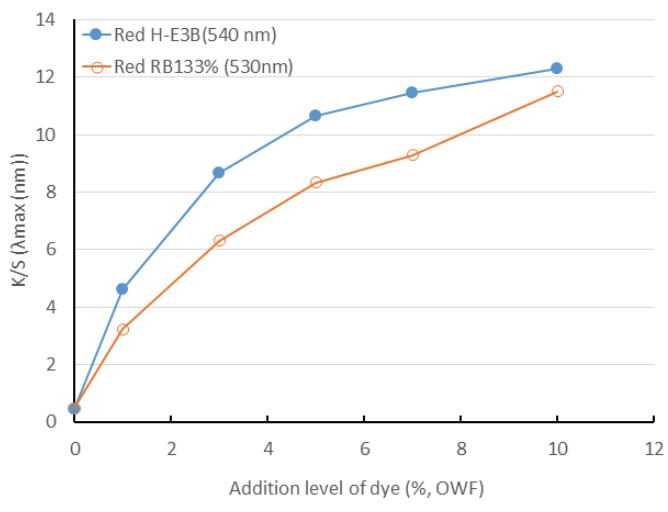

Fig. 2. Color yield of the dyed Re-WF by addition level of reactive dyes.

Fig. 3 denotes the color fastness of the regenerated fiber dyed with varying dye concentrations when compared with the color differences before and after UV irradiation for a certain time with an illumination of $0.67 \mathrm{~W} / \mathrm{m}^{2}$ at a temperature of $50^{\circ} \mathrm{C}$. This figure denotes that there was a large color difference in non-dyed woody fiber for MDF under UV irradiation. Although it was not possible to distinguish whether the discoloration of the dyed Re-WF under UV irradiation 


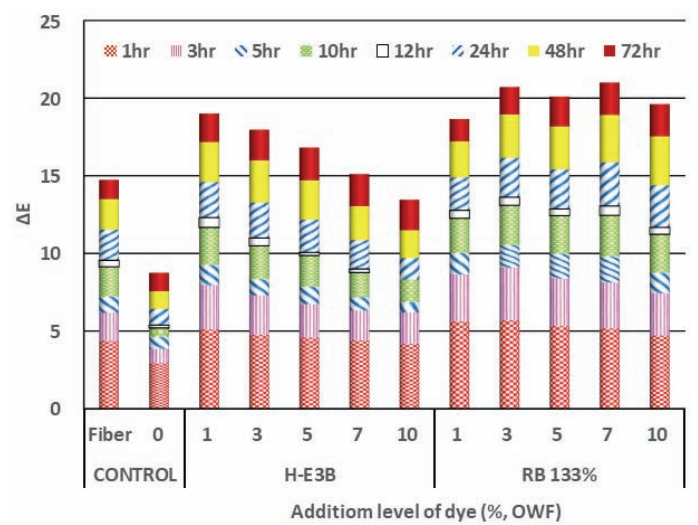

Fig. 3. Changes in color difference of dyed Re-WF by UV radiation time and addition level of reactive dyes.

was caused by the fiber itself or the dye, the color difference of the dyed fiber was larger than that of the non-dyed fiber. The K/S of H-E3B was higher than that of RB133\%; a lower color difference was observed using UV irradiation than that obtained using RB133\%, denoting better resistance to discoloration by UV irradiation. Furthermore, the color difference of the $\mathrm{H}-\mathrm{E} 3 \mathrm{~B}$ decreased as the dye concentration increased, while the color difference of RB133\% (including vinyl sulphone) comparatively increased.

\subsection{Effect of salt concentration on dyeing properties}

When cellulose is negatively charged in pure water and the dye is negatively charged as well, the approach and absorption of the dye to the fiber surface is interrupted because of the electrostatic resistance between the dye and fiber, resulting in weakening substantivity. If salt is added to the dyeing bath for improving the substantivity, the dye's approach to fiber becomes easier due to the salting out effect. While dyeing the Re-WF with the reactive dyes of the Bis-MCT/MCT type H-E3B and the Bis-MCT/VS type RB133\%, the colors and color difference obtained in accordance with the

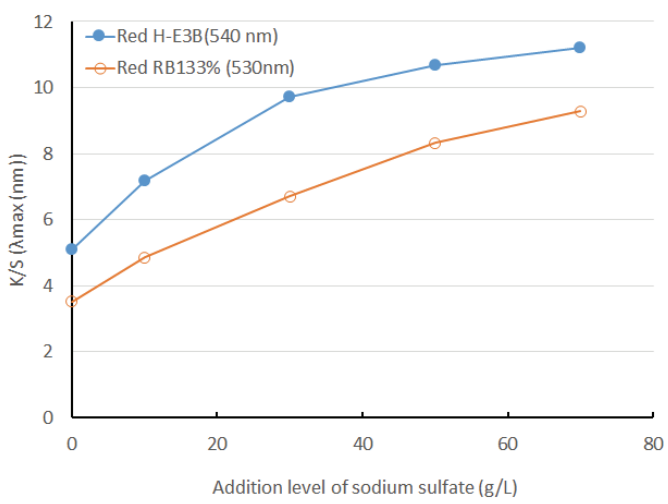

Fig. 4. Color yield of the dyed Re-WF with reactive dyes by addition level of sodium sulfate.

addition amounts of $\mathrm{Na}_{2} \mathrm{SO}_{4}(0,10,30,50$, and 70 $\mathrm{g} / \mathrm{L})$ were compared. The H-E3B and RB133\% dyes successfully formed colors with color differences of 48.1 and 41.5, respectively, when salt was not added. However, the color difference increased as the addition amount of salt increased, and H-E3B exhibited a larger color difference than that exhibited by RB133\% at all levels of salt additions.

The dyeing yield according to the salt concentration of the reactive dye is shown in Fig. 4. The dyeing yield of H-E3B with a maximum wavelength of 540 $\mathrm{nm}$ and that of RB133\% with a maximum wavelength of $530 \mathrm{~nm}$ considerably increased as the salt concentration increased from 0 to $70 \mathrm{~g} / \mathrm{L}$. The K/S of H-E3B was higher than that of RB133\% at all levels of salt concentrations.

The color fastness to light of the regenerated fiber dyed using varying addition amounts of salt was observed based on the color difference before and after the UV irradiation for a certain time. H-E3B was better than the RB133\% at all levels of salt concentrations. The color difference of H-E3B decreased as the addition amount of salt increased, whereas that of RB133\% slightly increased up to $30 \mathrm{~g} / \mathrm{L}$ but subsequently declined, indicating that $50-70 \mathrm{~g} / \mathrm{L}$ was the effective addition amount of salt. 
The Dyeing Properties of Woody Fiber Regenerated from Waste MDF by Reactive Dyes

\subsection{Effect of sodium carbonate on dyeing properties and color fastness}

To dyeing cellulose fiber using a reactive dye, the dye is fixed to fiber through Phase A, where the reactive dye is adsorbed onto the surface of cellulose and then permeated into the fiber, and Phase B, where a covalent bond, such as an ether bond, is formed between the reactive group of the dye (mainly vinyl sulphone or chlorotriazine) and the hydroxyl group of cellulose. This reaction depends on the functional group of the dye, the MCT system depends on nucleophilic substitution (SN2), and the VS system depends on the nucleophilic addition reaction. To stimulate such a reaction, sodium carbonate is added to convert the $\mathrm{pH}$ of dyeing bath to alkaline for promoting the ionization of cellulose- $(\mathrm{OH})$ n to cellulose-( $\left.\mathrm{O}^{-}\right)$n. Table 3 lists the $\mathrm{pH}$ of the dying bath at each dyeing process, according to the amount of sodium carbonate addition. However, the $\mathrm{pH}$ did not vary according to the dye type. The $\mathrm{pH}$ of the dyeing bath was maintained at 4.3-4.5 before sodium carbonate was added but was converted into alkali when sodium carbonate was added. The $\mathrm{pH}$ increased to $9.5-10.8$ as the addition amount increased.

While dyeing-Re-WF using the reactive dyes of the H-E3B and RB133\%, the color differences were compared according to the addition amounts of alkali (0, 2, 5, 10 and $20 \mathrm{~g} / \mathrm{L})$. Therefore, the color differences

Table 3. $\mathrm{pH}$ of each dyeing process

\begin{tabular}{|c|c|c|c|c|c|c|}
\hline \multirow{3}{*}{$\begin{array}{c}\text { Type of } \\
\text { dye }\end{array}$} & \multicolumn{6}{|c|}{$\mathrm{pH}$} \\
\hline & \multirow[b]{2}{*}{ Water } & $\mathrm{Na}_{2} \mathrm{SO}_{4}$ & \multicolumn{2}{|c|}{$\mathrm{Na}_{2} \mathrm{CO}_{3}$} & \multirow[b]{2}{*}{ Soaping } & \multirow[b]{2}{*}{ Fixing } \\
\hline & & 1st 2nd & $\begin{array}{c}\text { Amount } \\
(\mathrm{g} / \mathrm{L})\end{array}$ & $\mathrm{pH}$ & & \\
\hline \multirow{5}{*}{$\begin{array}{c}\text { Red } \\
\text { H-E3B, } \\
\text { Red RB } \\
133 \%\end{array}$} & \multirow{5}{*}{4.4} & \multirow{5}{*}{$4.3 \quad 4.4$} & 0 & 4.5 & \multirow{5}{*}{9.8} & \multirow{5}{*}{8.1} \\
\hline & & & 2 & 9.5 & & \\
\hline & & & 5 & 10.2 & & \\
\hline & & & 10 & 10.5 & & \\
\hline & & & 20 & 10.8 & & \\
\hline
\end{tabular}

of H-E3B and RB133\% were 46.0 and 18.75, respectively, when sodium carbonate was not included. Particularly, RB133\% dye of vinyl sulphone type did not properly form color until sodium carbonate was not added. However, the color difference considerably increased in $2 \mathrm{~g} / \mathrm{L}$ where the $\mathrm{pH}$ was converted to alkali with sodium carbonate was added in both dyes. There was almost no difference in color by the further addition of sodium carbonate.

The dyeing yields of H-E3B and RB133\% considerably increased while adding $2 \mathrm{~g} / \mathrm{L}$ of sodium carbonate, exhibiting almost the same tendency as that exhibited by color difference; further, almost no difference can be observed by the further addition of sodium carbonate (Fig. 5).

The color fastness to light of the regenerated dyed fiber with varying addition amounts of alkali was compared before and after UV irradiation for a certain time. The color difference of the H-E3B decreased as the addition amount of alkali increased, but RB133\% was almost not shown difference in the color difference until alkali was added $5 \mathrm{~g} / \mathrm{L}$ or more into Bis-MCT/VS type. Therefore, the result indicates that the adequate addition amount of sodium carbonate is $5-10 \mathrm{~g} / \mathrm{L}$ at $\mathrm{pH} 10$.

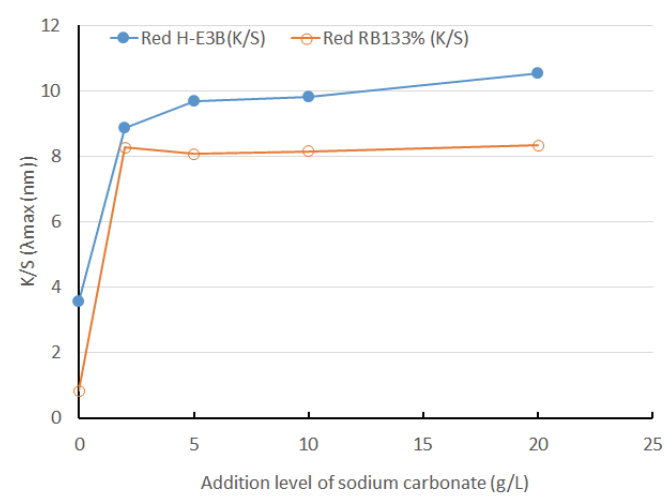

Fig. 5. Color yield of the dyed Re-WF with reactive dyes by addition level of sodium carbonate. 


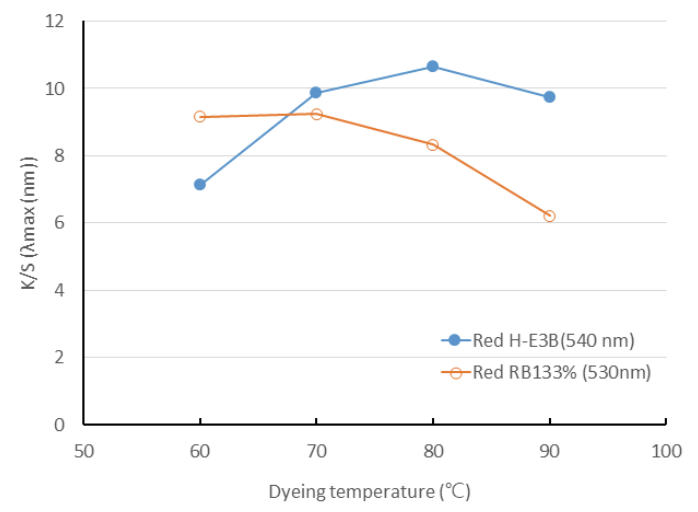

Fig. 6. Color yield of the dyed Re-WF with reactive dyes according to dyeing temperature.

\subsection{Effect of dyeing temperature on dyeing properties and color fastness}

As the dyeing temperature increases, the kinetic energy of the dye molecules increases, which further increases the dyeing speed reduces the time to reach the dyeing equilibrium, and affects the dyeing yield.

The colors and color differences were examined according to dyeing temperature in dyeing-Re-WF with the reactive dyes, such as H-E3B and RB 133\%. The colors of the Re-WF dyed with H-E3B according to varied temperatures were determined as $0.2 \mathrm{R}$ to $1.6 \mathrm{R}$. The color at a dyeing temperature of $60^{\circ} \mathrm{C}$ was red closer to RP becoming more red as the temperature increased. On the other side, the color difference between the non-dyed woody fiber and the dyed woody fiber ranged from 52.8 to 56.0, which increased from $60^{\circ} \mathrm{C}$ to $80^{\circ} \mathrm{C}$ but decreased at $90^{\circ} \mathrm{C}$. The color of Bis-MCT/VS type RB133\% was determined as reddish purple at 9.8 to $9.9 \mathrm{RP}$, almost closer to red, with almost no difference being observed by temperature. However, the color difference showed the decreasing tendency ranging from 49.1 to 54.7 as the temperature increased.

Fig. 6 depicts the dyeing yield of two types of reactive dyes. The dyeing yield of the H-E3B, where a covalent bond is formed through nucleophilic substitution (SN2), increased as the temperature increased but declined again at $80^{\circ} \mathrm{C}$. The $\mathrm{RB} 133 \%$ showed almost the same dyeing yield up to $60-70^{\circ} \mathrm{C}$ through nucleophilic substitution and addition reaction but subsequently decreased. This is presumably because the cellulose fiber is dyed with reactive dye through the simultaneous fixing reaction and hydrolysis and because the hydrolysis reaction rate is higher than fixation reaction rate during the rise in temperature. Therefore, the application of optimal temperature according to the dye is important, suggesting that $80^{\circ} \mathrm{C}$ and $60-70^{\circ} \mathrm{C}$ are adequate for H-E3B and RB 133\%, respectively.

\subsection{The effects of soaping and fixing agent treatment}

If the non-fixed dye is not sufficiently removed after dyeing is completed, the color fastness may deteriorate. Therefore, a soaping agent with high dispersibility and cleansing power is used to remove the non-fixed dye. Furthermore, the cationic fixing agent is mainly used to fix the reactive dye for preventing the repetition of readhesion and detachment of the fixed dye on fiber through hydrolysis. In terms of the color of a regenerated fiber that did not contain any dye, Fig. 7 depicts the color difference between the regenerated fiber dyed (W) that was dyed and simply washed with water for 70 min at $80^{\circ} \mathrm{C}$ with $5 \%$ dye (OWF), liquid ratio of 1:50, $50 \mathrm{~g} / \mathrm{L}$ of $\mathrm{Na}_{2} \mathrm{SO}_{4}$, and $20 \mathrm{~g} / \mathrm{L}$ of $\mathrm{Na}_{2} \mathrm{CO}_{3}$; with respect to the color of the dyed and soaping treatment fiber $(\mathrm{W}+\mathrm{S})$ that was treatment for $10 \mathrm{~min}$. at $90^{\circ} \mathrm{C}$ with a liquid ratio of 1:50 and $1 \mathrm{~g} / \mathrm{L}$ of the added soaping agent, the color difference of dyed, soaping, and fixation treatment $(\mathrm{W}+\mathrm{S}+\mathrm{F})$ fiber that had been fixed the dye to the fiber for $20 \mathrm{~min}$. at $60^{\circ} \mathrm{C}$ with the liquid ratio of 1:50 and $2 \%$ OWF of fixing agent added after soaping and cleansing.

For the two types of dyes, the color differences of the regenerated fiber that was washed, soaped, and fixed 
The Dyeing Properties of Woody Fiber Regenerated from Waste MDF by Reactive Dyes

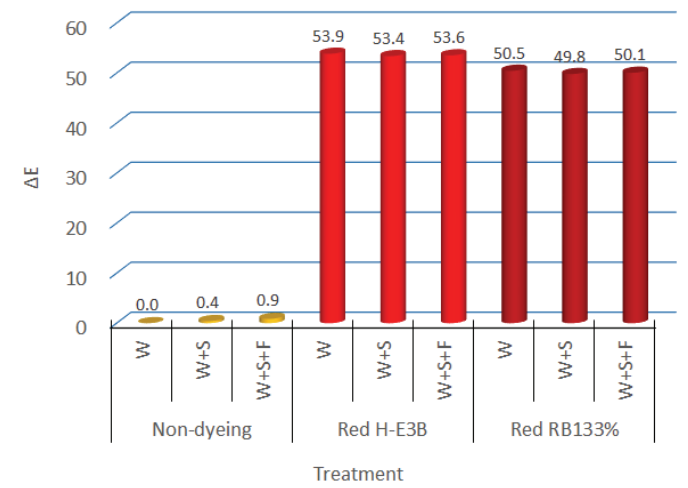

Fig. 7. Comparison of $\Delta \mathrm{E}$ by treatment process (Washing, Soaping and Fixation) for the dyed Re-WF with reactive dyes.

Notes : W : Water washing, S : Soaping, F : Fixation

without the addition of dye after each treatment were all below 0.5, which was evaluated as "trace" (color difference 0 to 0.5 ) according to the NBS. Furthermore, the colors of the regenerated fiber that was dyed with reactive H-E3B and RB133\% and then washed were $1.8 \mathrm{R}$ and 10.0RP, respectively. After the soaping treatment, the colors were $1.6 \mathrm{R}$ and $9.90 \mathrm{RP}$, whereas they were $1.6 \mathrm{R}$ and $10.0 \mathrm{RP}$ after fixing treatment, exhibiting only a minor difference. The color differences in the regenerated dyed $(\mathrm{W})$, soaped $(\mathrm{W}+\mathrm{S})$, and fixed $(\mathrm{W}+\mathrm{S}+\mathrm{F})$ fiber were determined as being at a similar level before and after UV irradiation for a certain time.

\section{CONCLUSION}

The findings regarding the influences on dyeing properties and color fastness to light due to dye concentrations, additional amounts of salt and alkali, and dyeing temperature in dyeing for Re-WF obtained from waste MDF manufactured with pitch pine and with the two types of reddish reactive dyes (H-3EB: bis-MCT/MCT and RB 133\%: bis-MCT/VS) are as follows:
The colors of the Re-WF dyed at a dyeing concentration of $1 \%$ to $10 \%$ with reactive H-E3B were determined as $0.2 \mathrm{R}$ to $3.6 \mathrm{R}$, ranging from red close to RP at low concentrations to a reddish color at higher concentrations. The color difference of the non-dyed Re-WF was 45.9 to 56.3 , which rapidly increased at low concentrations, but hardly varied at concentrations of $5 \%$ or higher. The colors of the Bis-MCT/VS type $\mathrm{RB} 133 \%$, ranging from 9.6RP to $10.0 \mathrm{RP}$, were determined as reddish purple closer to red at dyeing concentrations of $3 \%$ and $7 \%$, showing almost no color difference according to the dyeing concentration. The dyeing yield of the two types of dye increased as the dyeing concentration increased, and the K/S of H-E3B was higher than that of RB133\% at all the dyeing concentrations. The color difference obtained using UV irradiation was lower in RB133\% than that in H-E3B.

As the addition amount of sodium sulfate increased in H-E3B and RB133\% dyes, the color difference and $\mathrm{K} / \mathrm{S}$ increased and the color fastness to light was good. Therefore, the result suggests that the adequate addition amount of salt was 50-70 g/L.

The color difference and K/S of H-E3B and RB133\% considerably increased when the $\mathrm{pH}$ was converted into alkaline by adding $2 \mathrm{~g} / \mathrm{L}$ of sodium carbonate, but there was almost no difference by adding further amount of sodium carbonate. For H-E3B, the color difference before and after UV irradiation decreased when the addition amount of alkali increased; however, RB133\% showed almost no difference when the addition was $5 \mathrm{~g} / \mathrm{L}$ or more. Therefore, the adequate addition amount of sodium carbonate was $5-10 \mathrm{~g} / \mathrm{L}$ at $\mathrm{pH} 10$.

Even though the dyeing yield of H-E3B increased as the dyeing temperature increased but again decreased at $80^{\circ} \mathrm{C}$, the dyeing yield of $\mathrm{RB} 133 \%$ exhibited an almost identical up to $60-70^{\circ} \mathrm{C}$ but decreased subsequently. Therefore, the result suggests that the temperatures of $80^{\circ} \mathrm{C}$ and $60^{\circ} \mathrm{C}$ are adequate for H-E3B and RB133\%, respectively. 


\section{ACKNOWLEDGMENT}

This study was supported by the Gyeongnam National University of Science and Technology Grant.

\section{REFERENCES}

Bhatti, I.A., Zia, K.M. Ali, Z., Zuber, M., Rehman, F. 2012. Modification of cellulosic fibers to enhance their dyeability using UV-irradiation. Carbohydrate Polymers 89: 783-787.

CIBA-GEIGY. 1990. Dying of reactive dyes. Journal of the Korean Society of Dyers and Finishers 2(1): 44-67.

Hidayat, W., Qi Y., Jang, J.H., Park, B.H., Banuwa, I.S. Febrianto, F., Kim, N.H. 2017. Color change and consumer preferences towards color of heat-treated Korean white pine and royal paulownia woods. Journal of the Korean Wood Science and Technology 45(2): 213-222.

Jung, Y.J., Lee, Y.H., Park, S.M. and Kim, K.H. 1994. A study on dyeing properties of cationic agent treated cotton fiber with reactive dye. Journal of the Korean Society of Dyers and Finishers 6(4): 46-53.

Ju, S.G., Roh, J.K. 2017. Manufacture of Dyed Recycling Woody fiber Using Waste MDF Journal of the Korean Wood Science and Technology 45(3): 297-307.

Khatri, M., Ahmed, F., Jatoi, A.W., Kim, I.S., Mahar, R.B., Khatri, Z. 2016. Ultrasonic dyeing of cellulose nanofibers. Ultrasonics Sonochemistry 31: 350354.

Kim, M.R. Lee, H.J. Lee, J.J., 2010.The Effect of Sodium Sulfate in Liquid or Solid Form on Reactive Dyeing and Fastness Properties of Cellulose Knitted Fabric. Textile Coloration and Finishing 22(4):
341-348.

Koh, J.S., Kim, I.S., Kim, S.S. Shim, W.S., Kim, J.P. Kwak, S.Y. Chun, S.W., Kwon, Y.K. 2004. Dyeing Properties of Novel Regenerated Cellulosic Fibers. Journal of Applied Polymer Science 91(6): 34813488.

Koh, J.S., Kim, I.S., Kim, S.S. Shim, W.S., Kim, J.P., 2004. Dyeing properties of Bis-functional reactive dyes on a novel regenerated cellulosic fiber. Fibers and Polymers 5(1): 44-51.

Koh, J.S., Kim, I.S., Kim, S.S. Shim, W.S., Kim, J.P. 2005. Reactive dyeing properties of novel regenerated cellulosic fibres. Dyes and Pigments 64(1): 9-16.

Larik, S.A., Khatr, A. Ali, S. Kim. S.H. 2015. Batchwise dyeing of bamboo cellulose fabric with reactive dye using ultrasonic energy. Ultrasonics Sonochemistry 24: 178-183.

Lee, J.S., Choi, G.S. 2018. Development of coloring method of didecyldimethylammonium chloride (DDAC) in wood treated with alkaline copper quaternary (ACQ) preservative. Journal of the Korean Wood Science and Technology 46(3): 253-259.

Lee, S.K., Jo, H.J., Kim, Y.G., Lee, H.J., Kang, H.Y. 2006. Analysis of dyeing components from Neolitsea sericea Koidz bark. Journal of the Korean Wood Science and Technology 34(3): 64-72.

Moon. S.O., Kim, C.H., Kim, G.Y., Jung, H.G., Shin, T.G., Kim, J.G., Park, C.Y. 2007. Application of natural dyes for developing colored wood furniture (2) -Color variation by treatment methods of natural dyes-. Journal of the Korean Wood Science and Technology 35(3): 79-87.

Yoon, K.J., Eom, C.D., Park, J.H., Kim, H.Y., Choi, I.G., Lee,J.J., Yeo., H.M. 2009. Color control and durability improvement of yellow polar (Liriodendron tulipifera) by heat treatments. Journal of the Korean Wood Science and Technology 37(6): 487-496. 


\title{
APPENDIX
}

\author{
(Korean Version)
}

\section{반응성염료에 의한 폐MDF 재생 목질섬유의 염색특성}

초록 : 폐MDF로부터 해섬하여 얻은 재생섬유를 Reactive Red H-E3B (Bis-monochlorotriazine(MCT)/MCT type)와 Reactive Red RB 133\%(bis-monochlorotriazine/Vinyl sulphone type)로 염색할 때 최적의 염색조건을 구명하기 위하여 염색조 건(염료 농도, 염과 알칼리 첨가량, 염색온도)과 염색특성 및 일광견뢰도와의 관계를 검토하였다. 2종의 반응성염료 모두 염료농 도가 1 10(\%,OWF)로 증가함에 따라 염착량(K/S)은 증가하였다. 또한, H-E3B가 RB $133 \%$ 보다 염료 농도에 관계없이 K/S는 높았으며, 자외선 조사에 따른 색차는 낮아 자외선에 의한 변색 저항성이 양호하였다. 황산나트륨의 첨가량이 증가할수록 색차 및 K/S도 증가하였으며, 염의 첨가량은 $50 \sim 70 \mathrm{~g} / \mathrm{L}$ 가 적절하였다. $2 \mathrm{~g} / \mathrm{L}$ 의 탄산나트륨 첨가에 의해 색차 및 K/S가 크게 증가하였으나 그 이상의 첨가량 증가에서는 거의 차이가 없었다. 탄산나트륨의 첨가량은 $\mathrm{pH} 10$ 을 유지하는 $5 \sim 10 \mathrm{~g} / \mathrm{L}$ 가 적절할 것으로 생각된다. $\mathrm{H}-\mathrm{E} 3 \mathrm{~B}$ 염료는 염색 온도가 높아짐에 따라 염착량이 증가하다가 $80^{\circ} \mathrm{C}$ 에서 다시 감소한 반면 $\mathrm{RB}$ $133 \%$ 는 $60 \sim 70^{\circ} \mathrm{C}$ 까지는 거의 동일한 염착량을 나타냈으나, 이후 감소하였다. 따라서 $\mathrm{H}-\mathrm{E} 3 \mathrm{~B}$ 는 $80^{\circ} \mathrm{C}, \mathrm{RB} 133 \%$ 는 $60^{\circ} \mathrm{C}$ 가 적정한 것으로 판단된다. 이상의 최적조건에서 폐 $\mathrm{MDF}$ 목질섬유를 염색처리하면 $\mathrm{H}-\mathrm{E} 3 \mathrm{~B}$ 염료는 $1.5 \sim 2.0 \mathrm{R}, \mathrm{RB} 133 \%$ 염료는 9.6 10.0 PR의 색상을 가지는 염색 재생 목질섬유의 제조가 가능하였다.

\section{1. 서 론}

$\mathrm{MDF}$ (Medium density fiberboard)는 2006 2016년간 평균 국내 수요량이 215만 $\mathrm{m}^{3}$ /년으로 가장 많이 사용되고 있는 목질 패널 재료이다(FAO). 또한, 대부분이 가구와 건축내장재로 사용된 $\mathrm{MDF}$ 제품의 평균 수명을 10 년 정도로 가정한다면 앞으로

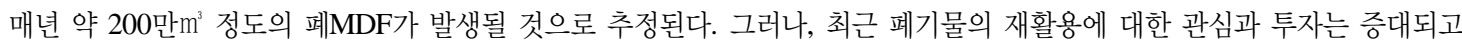
있으나, 국내에서 목질패널 중 가장 수요량이 많은 $\mathrm{MDF}$ 는 열적 재활용이 아닌 물질로서의 재활용은 아직 거의 이루어지지 않고 있다. 따라서 주변에서 쉽게 구할 수 있는 폐MDF를 이용하여 인테리어 소품 제조용의 원료로 이용하기 위해 전보에서는 염색 재생 목질섬유의 제조 가능성을 검토하였다(Ju and Roh, 2017). 그 결과 셀룰로오스계 섬유의 염색에 주로 이용되는 빨강, 노랑 및 파랑색 계열의 Bis-monochlorotriazine계와 Vinyl sulfone계의 반응성 염료 6종, Anthraquinone계인 배트염료 3종, Diazo계열의 직접염료 3종 및 치자와 소목의 천연염료에 의한 염색성 및 일광견뢰도를 비교 검토한 결과, 버진섬유와 재생섬유에 관계없이 염색섬유의 제조가 가능하다는 것을 확인하였으나 일광견뢰도는 불량하였다.

지금까지 목재나 목질재료의 색과 관련해서 ACQ 방부처된 목재의 색상(Lee and Choi, 2018), 열처리 목재의 색상 변화 (Hidayat et al., 2017 and Yoon et al., 2009). 천연 염색 방법에 의한 목재의 색 변이(Moon et al., 2007). 한지의 천연염료로서 참식나무 수피의 염료성분 분석(Lee et al., 2006) 등의 연구가 수행되었으나 반응성 염료에 의한 목질 섬유의 염색에 대한 연구는 없었다. 반면에 면의 셀룰로오스에 대해 반응성염료에 의한 염색과 관련된 연구로 고분자 화합물의 반응형 캐티온화제 처리 면섬유에 대한 반응성염료의 염색성(Jung et al., 1994), 3원색 반응성염료를 사용한 Cellulose 섬유 염색시 망초의 타입 및 투입량이 염색성 및 견뢰도에 미치는 영향(Kim et al., 2010), novel regenerated cellulosic fiber에 대한 염색특성(Koh et al., 2004; 2005) 재생 염색셀룰로오스 나노파이버(Bhatri et al., 2012; Khatri et al., 2016)와 대나무 섬유 직물(Larik et al., 2015)의 반응성염료 염색시 기존의 염색보다 ultrasonic energy 염색이 우수하다는 연구 등이 수행되었으나 재생 목질섬유에 대한 염색은 행해진 바가 없다. 반응성염료에 의한 염색은 셀룰로오스의 수산기와 염료의 반응기(주로 비닐술폰이나 클로로트리아진기)간에 부가나 치환반응에 의해 공유결합이 형성되므로 인해 발색되는 것으로 염색조건에 따른 색상과 견뢰도 에는 차이가 있다. 따라서 본 연구에서는 Bis-monochlorotriazine계와 Bis-monochlorotriazine / Vinyl sulphone계의 적색계 반응성염료를 사용하여 재생 목질섬유를 염색할 때 최적의 염색조건(OWF(On the Weight of Fiber), 온도, $\mathrm{pH}$, 보조제의 첨가량)을 구명하였다. 


\section{2. 재료 및 방법}

\section{1. 공시 재료}

\subsection{1. $\mathrm{MDF}$}

재생 목질섬유를 얻기 위한 MDF는 국내산 리기다소나무(Pitch pine (Pinus rigida M.)와 요소수지를 사용하여 제조한 두께 $12 \mathrm{~mm}$, 비중 0.62 의 $\mathrm{MDF}$ 를 업계로부터 분양받아 사용하였다.

\subsection{2. 염료 및 시약}

염료로는 셀룰로오스계 섬유의 염색에 주로 이용되고 있는 적색계열의 bis-MCT/MCT계인 Red H-E3B와 bis-MCT/MCT/ vinyl sulphone계인 Red RB 133\% 반응성염료를 사용하였다. 사용한 염료의 종류 및 주요 특성은 Table 1 과 같다. 황산나트륨, 탄산나트륨은 1급 시약을 그대로 사용하였다. Soaping제는 음이온성 SNOPOL SR-140(Snogen Co.)을, Fixing제로는 양이온성 의 SUPERFIX RF(Snogen Co.)를 사용하였다.

\section{2. 실험방법}

2.2.1. 재생섬유의 해리

$\mathrm{MDF}$ 로부터의 재생섬유는 $50 \times 50 \times 12 \mathrm{~mm}$ 로 절단한 $\mathrm{MDF}$ 에 $250 \mathrm{ml}$ 의 증류수를 첨가한 후 $25^{\circ} \mathrm{C}$ 에서 48 시간 침지처리한 후 가정용 믹서기에 의해 5 분간 해리한 다음 $300 \mu \mathrm{m}$ 의 스크린으로 여과한 후 건조하여 제조하였다.

\subsection{2. 염색}

전 염색과정은 Fig. 1 과 같다. 염색은 톨 비커에 재생섬유를 넣고, 염료 $5 \%(\mathrm{OWF})$, 액비 $1: 50, \mathrm{Na}_{2} \mathrm{SO}_{4} 50 \mathrm{~g} / \mathrm{L}, \mathrm{Na}_{2} \mathrm{CO}_{3}$ $20 \mathrm{~g} / \mathrm{L}, 80^{\circ} \mathrm{C}$ 에서 80 분을 기본 조건으로 각각의 염색 조건을 검토하였다. 염색 조건으로는 염료의 첨가량 $(0,1,3,5,7$ 및 $10 \%, \mathrm{OWF}), \mathrm{Na}_{2} \mathrm{SO}_{4}$ 첨가량 $(0,10,30,50$ 및 $70 \mathrm{~g} / \mathrm{L}), \mathrm{Na}_{2} \mathrm{CO}_{3}$ 첨가량 $(0,2,5,10$ 및 $30 \mathrm{~g} / \mathrm{L})$ 및 염색 온도 $(60,70,80$ 및 $90^{\circ} \mathrm{C}$ )를 달리하여 염색한 후, 소우핑(Soaping)은 액비 $1: 50$, 소우핑제 첨가량 $1 \mathrm{~g} / \mathrm{L}, 90^{\circ} \mathrm{C}$ 에서 10 분간 처리 후 수세하였으며, 고착(Fixing)처리는 액비 1:50에서 고착제 첨가량 $2(\%, \mathrm{OWF}), 60^{\circ} \mathrm{C}$ 에서 20 분간 처리 후 수세하였다.

2.2.3. 염색섬유의 시트제조

염착성, 색상 및 일광견뢰도를 측정하기 위한 시트는 2 종의 반응성염료에 의해 조건별로 염색한 재생염색섬유에 염액과 동량의 증류수를 첨가하여 소형 믹서기로 2 분간 처리한 후 whatman 여과지를 사용하여 여과한 후 $50^{\circ} \mathrm{C}$ 에서 5 분간 압체하여 제조하였다.

\subsection{4. 색 특성 측정}

재생 염색섬유의 표면색상은 Minolta CM-3800d (Japan)를 사용하여 측정하였으며, 염색에 따른 색차는 순수 재생 섬유시트 에 대한 차이로 구하였다. 자외선 조사후의 색차는 자외선 조사전후의 $\mathrm{L}^{*}, \mathrm{a}^{*}, \mathrm{~b}^{*}$ 의 차이로부터 산출하였다. $\mathrm{K} / \mathrm{S}$ 값은 각각 염색 시료의 표면 반사율을 측정한 후 다음과 같은 Kubelka-Munk식에 의해 산출하였다.

$$
\mathrm{K} / \mathrm{S}=(1-\mathrm{R})^{2} / 2 \mathrm{R}
$$

$\mathrm{K}$ : Absorption coefficient, S : Scattering coefficient, $\mathrm{R}$ : Reflectance coefficient

\subsection{5. 일광 견뢰도 평가}

각각의 염료에 의해 염색된 섬유로 제조한 시트의 일광 견뢰도는 촉진내후성 시험기(QUV/SP, USA)를 이용하여 UVB-313 램프, 조도 $0.67 \mathrm{~W} / \mathrm{m}^{2}$, 온도 $50^{\circ} \mathrm{C}$ 에서 일정시간 자외선 조사처리 전후의 CIELAB 색 공간에서의 색차로 평가하였다.

\section{3. 결과 및 고찰}

반응성염료에 의한 셀룰로오스계 섬유의 염색은 먼저 반응성염료가 셀룰로오스 표면에 흡착되고 섬유내부로 확산하는 단계 (Phase A)와 염료의 반응기(주로 비닐슬폰기나 클로로트리아진기)와 셀룰로오스의 수산기와의 사이에 에테르 결합과 같은 공유결합이 형성되는 단계(Phase B) 및 Phase $\mathrm{B}$ 에서 공유결합을 유도하기 위해 첨가한 알칼리를 제거하여 가수분해나 섬유의 
The Dyeing Properties of Woody Fiber Regenerated from Waste MDF by Reactive Dyes

손상을 방지하고 미반응의 염료를 제거하기 위한 세척 및 고착단계(Phase C)로 이루어진다(CIBA-GEIGY, 1990). 또한, 각 단계별 적용하는 조건에 따라 염색성에는 차이가 있다. 따라서 염료의 확산에 직접적으로 영향하는 염료의 농도, 셀룰로오스와 염료의 음이온 간의 정전기적인 반발의 완화시켜주는(Donnan potential) 불활성염인 황산나트륨의 첨가량, 알칼리 촉매로서 친핵성 치환반응(SN2) 또는 부가반응을 촉진시키기 위해 첨가하는 탄산나트륨의 첨가량 및 반응과 분해속도에 영향하는 염색온 도와 염착성과의 관계를 검토하였다.

3.1. 염료의 농도와 염색성 및 일광견뢰도

반응성염료에 의한 셀룰로오스계 섬유의 염색성은 Phase A에서 섬유와 수용성 염액간의 염료분포인 직접성(Substantivity)이 매우 중요하다. 셀룰로오스 섬유의 표면에 흡착될 수 있는 염료량은 제한적이기 때문에 표면이 포화되게 되는 농도 이상의 염료 첨가는 직접성을 감소시키는 요인이 된다.

Bis-MCT/MCT 계인 H-E3B와 Bis-MCT/VS계인 RB 133\%의 반응성염료로 재생 목질섬유를 염색할 때 염료의 농도에 따른 색상과 색차는 Table 2와 같다. 먼저 재생 목질섬유(대조구 : Control)와 염료를 첨가하지 않고 동일한 염색처리를 한 재생 목질섬유의 색상은 $0.2 \mathrm{Y}$ 및 $0.4 \mathrm{Y}$ 로 약간의 적황색(YR)기미가 있는 황색을 나타내고 있다. 또한 대조구에 비해 염료가 첨가되지 않고 동일한 염색처리를 한 재생 목질섬유는 가열과 첨가물질들로 인해 명도가 감소하고 채도가 약간 증가하였으며, 색차가 3.8로 미국의 염색물 색상차의 규정(NBS: National Bureau Standard) 에 따르면 “appreciable"(색차 3.6 6.0)에 해당된다.

$\mathrm{H}-\mathrm{E} 3 \mathrm{~B}$ 염료의 경우 $1 \% \sim 10 \%$ 의 염료 농도에 따른 색상은 $0.2 \mathrm{R} \sim 2.6 \mathrm{R}$ 로 저농도에서는 적자(RP)에 가까운 적색에서 농도가 높아지면 보다 적색의 색상을 나타내었다. 반면 미염색 재생 목질섬유에 대한 염색섬유의 색차는 45.9 56.3으로 저 농도에서는 급격히 증가하였으나, $5 \%$ 이상의 농도에서는 거의 차이가 없었다. Bis-MCT/VS계인 RB $133 \%$ 의 색상은 염료 농도 $1 \%$ 와 $10 \%$ 에서는 각각 $0.6 \mathrm{R}$ 과 $0.7 \mathrm{R}, 9.6 \sim 10.0 \mathrm{RP}$ 로 거의 적색에 가까운 적자색으로 염료 농도에 따른 색상의 차이는 거의 없었다. 반면에 색차는 38.6 55.7로 염료의 농도가 증가함에 따라 증가하는 경향을 나타내고 있다.

반응성염료의 염료농도에 따른 염착량은 Fig. 2와 같다. H-E3B(최대파장 540nm)와 RB $133 \%$ (최대파장 530nm)의 염착량은 염료의 농도가 $1 \%$ 에서 $10 \%$ 로 증가함에 따라 증가하였다. Bis-MCT/MCT계인 H-E3B와 Bis-MCT/VS계인 RB $133 \%$ 의 K/S는 모든 염료 농도에서 H-E3B가 RB $133 \%$ 보다 높았다. 따라서 목표하는 색상에 따라 적절한 염료의 첨가량을 조절할 필요가 있을 것으로 생각되며, 농도 $10 \%$ 까지는 농도가 증가하면 보다 적색에 가까운 색상을 얻을 수 있을 것으로 생각된다.

염료의 농도를 달리하여 염색한 재생염색섬유에 대해 조도 $0.67 \mathrm{~W} / \mathrm{m}^{2}$, 온도 $50^{\circ} \mathrm{C}$ 에서 일정시간 자외선 조사처리 전후의 색차로 비교한 일광견뢰도는 Fig. 3과 같다. 염료에 의해 염색하지 않은 MDF용의 목질섬유도 자외선의 조사에 의해 색차가 크게 나타나는 것을 확인할 수 있었다. 따라서 염색한 재생 목질섬유의 자외선에 의한 변색이 섬유자체의 의한 것인지 염료에 의한 것인지 구분할 수는 없지만 미염색섬유에 비해 염색섬유에서의 색차가 더 크게 나타났다. Bis-MCT/MCT계인 H-E3B와 Bis-MCT/VS계인 RB 133\%의 K/S는 모든 염료 농도에서 H-E3B가 RB 133\%보다 높았으며, 자외선 조사에 따른 색차는 $\mathrm{H}-\mathrm{E} 3 \mathrm{~B}$ 가 RB $133 \%$ 보다 낮아 자외선에 의한 변색 저항성도 보다 양호한 것으로 생각된다. 또한 MCT계인 H-E3B염료는 염료의 농도가 높아질수록 색차가 감소한 반면, 비닐슬폰기가 포함된 RB $133 \%$ 는 색차가 다소 커지는 경향을 나타내었다.

\section{2. 염의 농도와 염색성}

셀룰로오스는 순수 물에서는 음전하로 하전되고, 염료 또한 음전하로 하전되면 염료와 섬유간에는 정전기적인 반발로 인해 염료가 섬유표면에로의 접근과 흡착을 방해받게 되어 직접성이 악화된다. 이를 개선하기 위하여 염욕에 염(Salt)을 첨가하게 되면 염석(Salting out) 효과로 인해 염료의 접근이 용이해진다. Bis-MCT/MCT 계인 H-E3B와 Bis-MCT/VS계인 RB 133\%의 반응성염료에 의해 재생 목질섬유를 염색할 때 $\mathrm{Na}_{2} \mathrm{SO}_{4}$ 의 첨가량 $(0,10,30,50$ 및 $70 \mathrm{~g} / \mathrm{L})$ 에 따른 색상과 색차를 비교한 결과, H-E3B와 RB $133 \%$ 의 2종의 염료 모두 염을 첨가하지 않았을 때의 색차는 48.1과 41.5로 착색은 되었다. 그러나 염의 첨가량이 증가할수록 색차도 커졌으며, H-E3B가 RB $133 \%$ 보다 모든 염의 첨가수준에서 큰 색차값을 나타내었다.

반응성염료의 염농도에 따른 염착량은 Fig. 4와 같다. 최대파장 $540 \mathrm{~nm}$ 의 H-E3B와 최대파장 $530 \mathrm{~nm}$ 의 RB $133 \%$ 의 염착량은 염의 농도가 0 에서 $70 \mathrm{~g} / \mathrm{L}$ 로 증가함에 따라 크게 증가하였다. H-E3B의 K/S는 모든 염의 농도에서 RB $133 \%$ 보다 높았다.

염의 첨가량을 달리하여 염색한 재생 염색섬유에 대해 조도 $0.67 \mathrm{~W} / \mathrm{m}^{2}$, 온도 $50^{\circ} \mathrm{C}$ 에서 일정시간 자외선 조사처리 전후의 색차로 비교한 일광견뢰도는 모든 염의 농도에서 Bis-MCT/MCT계인 H-E3B가 Bis-MCT/VS계인 RB 133\%보다 양호하였다. $\mathrm{H}-\mathrm{E} 3 \mathrm{~B}$ 염료는 염의 첨가량이 증가할수록 색차가 감소하였으며, RB $133 \%$ 는 $30 \mathrm{~g} / \mathrm{L}$ 까지는 약간 증가하였으나 이후에는 감소하는 것으로부터 $50 \sim 70 \mathrm{~g} / \mathrm{L}$ 의 염의 첨가가 효과적일 것으로 생각된다. 


\section{3. 탄산나트륨의 첨가량과 염색성 및 일광견뢰도}

반응성염료에 의한 셀룰로오스계 섬유의 염색은 먼저 반응성염료가 셀룰로오스 표면에 흡착되고 섬유내부로 확산하는 단계 (Phase A)를 지나 염료의 반응기(주로 비닐슬폰기나 클로로트리아진기)와 셀룰로오스의 수산기와의 사이에 에테르 결합과 같은 공유결합이 형성되는 단계(Phase B)에 의해 염료가 고착된다. 이 반응은 염료의 관능기에 의해 좌우되며 MCT계는 친핵성 치환반응(Nucleophilic substitution : SN2)에 의해, VS 계는 친핵성 부가반응(Addition reaction)에 의해 이루어진다. 이 반응을 촉진하기 위해서는 Cellulose-(OH)n을 Cellulose-(O)n로의 이온화를 촉진하기 위해 염욕의 $\mathrm{pH}$ 를 알칼리성으로 전환하기 위해 탄산나트륨을 첨가한다. 전 염색과정 및 탄산나트륨 첨가량에 따른 염욕의 $\mathrm{pH}$ 는 Table 3 과 같다. 염료의 종류에 따른 $\mathrm{pH}$ 는 거의 차이가 없었다. 염욕의 $\mathrm{pH}$ 는 탄산나트륨을 첨가하기 전까지는 4.3 4.5 정도를 유지하다가 탄산나트륨을 첨가함으로 인해 알칼리로 전환되었으며, 첨가량이 많아질수록 $\mathrm{pH}$ 는 9.5 10.8로 높아졌다.

Bis-MCT/MCT 계인 H-E3B와 Bis-MCT/VS계인 RB $133 \%$ 의 반응성염료에 의해 재생 목질섬유를 염색할 때 알칼리의 첨가량 $(0,2,5,10$ 및 $20 \mathrm{~g} / \mathrm{L})$ 에 따른 색상과 색차를 비교한 결과, H-E3B와 RB 133\%의 2종 염료 모두 탄산나트륨을 첨가하지 않았을 때의 색차는 46.0 과 18.75 였다. 특히 비닐슬폰계인 RB $133 \%$ 염료는 탄산나트륨을 첨가하지 않으면 충분한 발색이 이루어지지 않았다. 그러나 두 염료 모두 탄산나트륨을 첨가하여 $\mathrm{pH}$ 가 알칼리로 전환된 $2 \mathrm{~g} / \mathrm{L}$ 에서 색차가 크게 증가하였으나 그 이상의 첨가량 증가에 따른 색차의 차이는 거의 없었다.

반응성염료의 알칼리 농도에 따른 염착량은 Fig. 5 와 같다. H-E3B와 RB $133 \%$ 의 염착량은 색차와 거의 같은 경향으로 탄산나트륨의 첨가량 $2 \mathrm{~g} / \mathrm{L}$ 에서 크게 증가하였으나 그 이상의 첨가량에서는 거의 차이가 없었다.

알칼리의 첨가량을 달리하여 염색한 재생염색섬유에 대해 조도 $0.67 \mathrm{~W} / \mathrm{m}^{2}$, 온도 $50^{\circ} \mathrm{C}$ 에서 일정시간 자외선 조사처리 전후의 색차로 비교한 일광견뢰도는 Bis-MCT/MCT계인 H-E3B염료의 경우는 알칼리의 첨가량이 증가할수록 색차가 감소하였으나, Bis-MCT/VS계인 RB $133 \%$ 는 $5 \mathrm{~g} / \mathrm{L}$ 이상 첨가에서는 거의 차이가 없었다. 따라서 탄산나트륨의 첨가량은 $\mathrm{pH} 10$ 을 유지하는 $5 \sim 10 \mathrm{~g} / \mathrm{L}$ 가 적절할 것으로 생각된다.

\section{4. 염색 온도와 염색성}

염색 온도가 높아지게 되면 염료분자의 운동에너지가 증가하여 염료의 염착속도를 증가시키고 염착평형 도달시간을 단축하 며, 고착량에도 영향을 미치게 된다. Bis-MCT/MCT 계인 H-E3B와 Bis-MCT/VS계인 RB $133 \%$ 의 반응성염료에 의해 재생 목질섬유를 염색할 때 염색온도에 따른 색상과 색차를 검토한 결과, H-E3B 염료의 경우 온도에 따른 색상은 $0.2 \mathrm{R} \sim 1.6 \mathrm{R}$ 로 $60^{\circ} \mathrm{C}$ 에서는 적자(RP)에 가까운 적색에서 온도가 높아지면 보다 적색의 색상에 가까워졌다. 반면 미염색 재생 목질섬유에 대한 염색섬유의 색차는 $52.8 \sim 56.0$ 으로 $60^{\circ} \mathrm{C}$ 에서 $80^{\circ} \mathrm{C}$ 까지는 증가하였으나, $90^{\circ} \mathrm{C}$ 에서는 오히려 감소하였다. Bis-MCT/VS계인 $\mathrm{RB} 133 \%$ 의 색상은 9.8 9.9RP로 거의 적색에 가까운 적자색으로 온도에 따른 차이는 거의 없었다. 반면에 색차는 49.1 54.7로 온도가 증가함에 따라 감소하는 경향을 나타내고 있다.

2종 반응성염료의 염착량은 Fig. 6과 같다. 친핵성 치환반응(Nucleophilic substitution : SN2) 에 의해 공유결합이 형성되는 Bis-MCT/MCT계인 H-E3B 염료는 온도가 높아짐에 따라 염착량이 증가하다가 $80^{\circ} \mathrm{C}$ 에서 다시 감소하였다. 친핵성 치환반응과 부가반응(Addition reaction)에 의한 Bis-MCT/VS계인 RB $133 \%$ 는 $60 \sim 70^{\circ} \mathrm{C}$ 까지는 거의 동일한 염착량을 나타냈으나, 이후 감소하였다. 이는 반응성염료에 의한 셀룰로오스계 섬유의 염색은 고착반응과 가수분해 반응이 동시에 일어나고 있고, 온도의 상승에 의해 고착반응 속도 보다는 가수분해 반응 속도가 크기 때문이라고 생각된다. 따라서 염료에 따라 최적의 온도 적용이 중요하며, $\mathrm{H}-\mathrm{E} 3 \mathrm{~B}$ 는 $80^{\circ} \mathrm{C}$ 가, $\mathrm{RB} 133 \%$ 염료는 $60 \sim 70^{\circ} \mathrm{C}$ 가 적절하였다.

\section{5. 소우핑과 고착제 처리의 영향}

염색처리가 완료되고 나서 섬유에 고착되지 않은 염료를 충분히 제거하지 않으면 견뢰도를 저하시키는 원인으로 작용한다고 알려져 있다. 따라서 미고착 염료를 제거하기 위해 분산성과 세척성이 높은 소우핑제를 사용하여 세척한다. 또한 고착된 염료도 가수분해에 의해 섬유에의 재부착과 탈리를 반복하게 되어 이를 방지하기 위해 반응성염료의 경우에는 주로 양이온성 고착제를 사용하여 고착처리 한다. 따라서 염료를 첨가하지 않은 재생섬유의 색에 대해 염료 $5 \%(\mathrm{OWF})$, 액비 1:50, $\mathrm{Na}_{2} \mathrm{SO}_{4} 50 \mathrm{~g} / \mathrm{L}$, $\mathrm{Na}_{2} \mathrm{CO}_{3} 20 \mathrm{~g} / \mathrm{L}, 80^{\circ} \mathrm{C}$ 에서 70 분 염색처리한 후 단지 수세한 재생섬유의 색차와, 액비 $1: 50$, 소우핑제 첨가량 $1 \mathrm{~g} / \mathrm{L}, 90^{\circ} \mathrm{C}$ 에서 10 분간 처리 후 수세한 염색섬유의 색 및 소우핑과 세척 처리후 액비 1:50에서 고착제 첨가량 $2 \%(\%, \mathrm{OWF}), 60^{\circ} \mathrm{C}$ 에서 20 분간 고착처리 후 수세한 재생섬유의 색차를 비교한 결과는 Fig. 7과 같다. 염료를 첨가하지 않고 수세와 소우핑 처리 및 고착처리를 한 재생섬유에 대한 각각의 처리후의 색차는 2종의 염료 모두 0.5이하로 미국의 염색물 색상차의 규정(NBS: National Bureau 
Standard) 에 따르면 “trace”(색차 0 0.5)에 해당된다. 또한 반응성 H-E3B와 RB $133 \%$ 염료로 염색한 후 수세한 재생섬유의 색상은 각각 $1.8 \mathrm{R}$ 과 $10.0 \mathrm{RP}$ 였으며, 소우핑 처리후는 $1.6 \mathrm{R}$ 과 9.90RP, 고착처리후는 $1.6 \mathrm{R}$ 과 $10.0 \mathrm{RP}$ 로 거의 차이가 없었다. 또한 2 종의 적색계 반응성염료로 염색시 소우핑과 고착처리에 따른 재생염색섬유에 대해 일정시간 자외선 조사처리 전후의 색차로 비교한 일광견뢰도는 2종의 염료 모두 거의 차이가 없었다.

\section{4. 결 론}

리기다소나무로 제조한 폐MDF로부터 얻은 재생섬유에 대해 적색계의 bis-MCT/MCT계와 bis-MCT/MCT/ Vinyl sulphone 계의 반응성염료로 염색시 염료의 농도, 염의 첨가량, 알칼리 첨가량, 염색온도에 따른 염색특성 및 일광견뢰도를 검토한 결과는 다음과 같다.

폐MDF의 재생섬유를 반응성 H-E3B 염료로 염료농도 1 10\%에서 염색한 염색재생섬유의 색상은 $0.2 \mathrm{R} \sim 2.6 \mathrm{R}$ 로 저농도에 서는 적자(RP)에 가까운 적색에서 농도가 높아지면 보다 적색을 나타내었다. 미염색 재생 목질섬유에 대한 염색섬유의 색차는 45.9 56.3으로 저 농도에서는 급격히 증가하였으나, $5 \%$ 이상의 농도에서는 거의 차이가 없었다. Bis-MCT/VS계인 RB $133 \%$ 의 색상은 염료 농도 $3 \%$ 와 7\%에서 9.6 10.0RP로 거의 적색에 가까운 적자색으로 염료 농도에 따른 색상의 차이는 거의 없었다. 2종의 염료 모두 염료농도가 증가함에 따라 염착량은 증가하였으며, 모든 염료 농도에서 H-E3B가 RB $133 \%$ 보다 $\mathrm{K} / \mathrm{S}$ 가 높았다. 자외선 조사에 따른 색차는 H-E3B가 RB $133 \%$ 보다 낮아 자외선에 의한 변색 저항성이 양호하였다.

H-E3B 및 RB 133\% 염료 모두 염색시 황산나트륨의 첨가량이 증가할수록 색차 및 K/S도 증가하였으며, 자외선 조사처리 전후의 색차로 비교한 일광견뢰도도 양호하였다. 따라서 염의 첨가량은 $50 \sim 70 \mathrm{~g} / \mathrm{L}$ 가 적절할 것으로 생각된다.

$\mathrm{H}-\mathrm{E} 3 \mathrm{~B}$ 및 RB 133\% 염료 모두 염색시 탄산나트륨을 첨가하여 $\mathrm{pH}$ 가 알칼리로 전환된 $2 \mathrm{~g} / \mathrm{L}$ 에서 색차 및 $\mathrm{K} / \mathrm{S}$ 가 크게 증가하였으나 그 이상의 첨가량 증가에서는 거의 차이가 없었다. $\mathrm{H}-\mathrm{E} 3 \mathrm{~B}$ 염료의 경우는 자외선 조사처리 전후의 색차가 알칼리의 첨가량이 증가할수록 감소하였으나, RB $133 \%$ 는 $5 \mathrm{~g} / \mathrm{L}$ 이상 첨가에서는 거의 차이가 없었다. 따라서 탄산나트륨의 첨가량은 $\mathrm{pH} 10$ 을 유지하는 5 10 g/L가 적절할 것으로 생각된다.

$\mathrm{H}-\mathrm{EBB}$ 염료는 염색 온도가 높아짐에 따라 염착량이 증가하다가 $80^{\circ} \mathrm{C}$ 에서 다시 감소한 반면 $\mathrm{RB} 133 \%$ 는 $60 \sim 70^{\circ} \mathrm{C}$ 까지는 거의 동일한 염착량을 나타냈으나, 이후 감소하였다. 따라서 $\mathrm{H}-\mathrm{E} 3 \mathrm{~B}$ 는 $80^{\circ} \mathrm{C}, \mathrm{RB} 133 \%$ 는 $60^{\circ} \mathrm{C}$ 가 적정한 것으로 판단된다. 